\author{
Sławomir FRANEK, PhD, Professor US \\ Institute of Economics and Finance, University of Szczecin \\ e-mail: slawomir.franek@usz.edu.pl \\ ORCID: 0000-0002-9698-4918
}

DOI: $10.15290 /$ oes.2020.04.102.05

\title{
MULTIANNUAL EXPENDITURES IN STATE BUDGET AND LOCAL GOVERNMENT BUDGETS IN POLAND ${ }^{1}$
}

\begin{abstract}
Summary
Purpose - The purpose of the article is to assess the significance of multiannual expenditures in the state and budgets of local government units in Poland.

Research method - In order to achieve the objective, the methods of comparative analysis of budget expenditures extending beyond one financial year of the state and local government units were used. The research period covers the years 2014-2018. The source of data utilised for the analyses are reports relating to the performance of the state budget and information on the performance of the budgets of local government units, as well as databases on multiannual financial forecasts of local government units.

The analysis used data on expenditure related to the implementation of multiannual programmes (in the state budget) and expenditure on undertakings shown in multiannual financial forecasts (in the budgets of local government units). The analysis also included the non-expiring expenditures. Therefore, it was possible to indicate the share of expenditures extending beyond one financial year in the budgets executed annually.

Results - The research results indicate that despite the existence of solutions for long-term budget planning at the level of the state and local government units in Poland, the scale of implementation of multiannual expenditures in annual budgets remains relatively small. In addition, differences in the implementation of multiannual expenditures between specific categories of local government units were pointed out.
\end{abstract}

Keywords: multiannual budget, public finance, local government finance

JEL Classification: H50, H61, H72

\section{Introduction}

Recent years have been conducive to the implementation of solutions assuming the extension of the budget horizon beyond the budget year. This is reflected in the application of the medium-term budgetary framework in numerous countries. An overview of such solutions can be found in the paper by Sherwood [2015] and in

${ }^{1}$ Article received on 28 March 2020, accepted on 29 May 2020. 
a report of the network of independent fiscal institutions of the European Union [EU IFIs, 2018]. These trends are reinforced by relevant regulations, as expressed at the EU level by the Council Directive 2011/85/EU of $8^{\text {th }}$ November 2011 on the requirements for budgetary frameworks of the Member States [2011], the content of which indicates that the one-year perspective is not an appropriate basis for prudent fiscal policy. Hence, the proposal to include a multiannual fiscal perspective in the EU fiscal surveillance framework. Previously, Wildavsky [1986, p. 317] pointed out that focusing on the annual budget leads to short-termism and concealing future expenditures. It is also a manifestation of conservatism and a limited perception of budgetary processes. It is evident that many publicly funded projects require a longterm perspective, going far beyond a one-year budget. This applies not only to investment tasks that naturally go beyond the one-year period, but also to many other undertakings that require an extended implementation perspective to achieve the assumed results. The one year framework of a budget is treated as a limitation of flexibility. Frequently, during the financial year, unforeseen events occur, resulting in the necessity to reallocate funds. It is common that the need to adhere to the annuality principle is the source of inefficiency in the public finance sector. This is manifested by spending funds in the final weeks of the financial year, regardless of their substantive justification, caused only by the motivation to use the budgeted amounts as fully as possible.

The increased importance of the multiannual approach in the budget process in Poland is taken into account in the Multiannual State Financial Plan (WPFP Wieloletni Plan Finansowy Państwa) and the Multiannual Financial Forecasts (WPF Wieloletnie Prognosy Finansowe) of local government units (LGUs) regulated by the Public Finance Act [Act, 2009]. In Polish subject literature, most of the publications devoted to these solutions focus on formal and legal aspects of their functioning, for example works by Salachna [2015, 2016], Ruśkowski [Rocżność..., 2014] and Jędrzejczyk [2020]. There are also studies on the role of these tools in public finance management processes. This aspect is discussed in the works by Uryszek [2018], Postuła [2017], Filipiak [2016], Dylewski [2016] and Franek [2013].

It should however be noted, that no significant progress has been made in the implementation of the provisions of the document entitled Assumptions to Budget System Reforms [2016], which assumes, among other things, integration of multiannual planning with the annual budget. This means that there are no hard-budgetary constraints in the WPFP that would link annual and multiannual budget planning. As a consequence, the value of the MTBF Index published annually by the European Commission (the latest available data for 2017) showing the importance of budget planning in the budget process ranks Poland in the penultimate position amongst the EU states. The low value of this index is influenced by the fact that one of the criteria taken into account in the calculation of this index is the level of relationships between the medium-term frameworks and the annual budgets. For this criterion, the medium-term budgetary framework in Poland scored zero points.

In such a context, WPFs determine the shape of LGU budgets much more strongly than the WPFP influences the shape of the state budget. This is a result of 
the regulations assuming the necessity of compliance of the multiannual financial forecast with the LGU budget in terms of result and debt [Act, 2009, art. 229] and setting the limits of spending on undertakings for subsequent years in the WPF, which constitute the basis for incurring liabilities.

Therefore, the aim of this article is to assess the significance of long-term expenditures in the state budget and budgets of local government units in Poland. As long-term expenditures were considered as those that result from contracting commitments extending beyond one financial year on the basis of the regulations set out in the Public Finance Act, the assessment includes the state budget expenditures on long-term programs, non-expiring expenditures of the state budget and LGU budgets, as well as spending on undertakings set out in the WPF of local government units.

\section{Aberrations from the annuality principle in the public finance system}

One of the fundamental budgetary principles is the annuality principle, which assumes limiting the time horizon of the budget plan to one year. The expression of its importance is the provision contained in Article 219, paragraph 1 of the Constitution of the Republic of Poland, according to which "the Sejm shall adopt the State Budget for the financial year by means of a Budget Act". This principle is also reflected in the provisions of the Public Finance Act, according to which the Budget Act as the basis for the state financial economy in a given financial year (identical to the calendar year) is passed for the period of one financial year [Act, 2009, art. 106]. It is similar in the case of the budgets of local government units for which the basis of their financial economy in a given financial year is the budget resolution passed for the period of one financial year [Act, 2009, art. 211]. In the case of financial plans of units from the public finance sector, it is indicated that annual financial plans are the basis of their financial economy. This applies to local government budget companies, executive agencies, budget economy institutions, and state special purpose funds [Act, 2009, art. 15 par. 2, art. 21 par. 1, art. 24 par. 2, art. 29 par. 6]. It should also be pointed out that, as a rule, the amounts recorded in the plan of spending or costs of the public finance sector unit (reduced by expenses on salaries and wages, social security contributions and the Labour Fund, other obligatory contributions and fees, and payments resulting from commitments made in previous years) constitute the limit up to which commitments may be made in a given year [Act, 2009, art. 46].

Exceptions from this rule include options of incurring obligations related to the implementation of multiannual programmes [Act, 2009, art. 136 par. 4], as well as the possibility of financing to be provided by the Minister of Finance [Act, 2009, art. 153]. It should also be emphasised that the exceptions to the annuality principle are also solutions allowing for the possibility of performing budgetary expenditures related to a given year also after its completion.

Naturally, respecting the annuality principle does not only refer to the issue of budget planning, but has consequences in the form of the necessity to close 
financial operations made with the use of budget funds within a fixed period of time, i.e. within the limits of the budget year. Thus, planned revenues and/or expenses not executed during the financial year generally expire, and their possible continuation in subsequent periods depends on their inclusion in the new budget. This raises the problem of multiannual budget planning, with the recognition that practical requirements and planning techniques should force a shift away from the traditional principle of budget annuality towards its replacement by the principle of multiannual budgeting, which was already postulated many years ago [Gajl, 1986, p. 126].

It should be stressed that the concept of multiannual spending should not be equated with the concept of fixed expenditure. The term "fixed expenditures" (also known as "legally determined expenditures") is used to describe all expenditures whose amount results from laws other than the Budget Act or commitments previously entered into within the legal framework [Ruśkowski, 2015; Owsiak, 2017, p. 844]. The multiannual budget expenditures can be considered to be those resulting from commitments undertaken for a period beyond the budget year on the basis of regulations specified in the Public Finance Act. This means that multiannual expenditures can be treated as one of the components of fixed expenditures. Therefore, the thorough analysis included the state budget expenditures on multiannual programs, non-expiring expenditures in the state budget and budgets of local government units, and expenditures on undertakings.

\section{State budget expenditure on multiannual programmes}

Projects called "multiannual programs" are characterised by their special nature. They are related to the state budget in such a way that the budget expenses reflect the spending incurred for a given programme in the budget year and those expected in subsequent years. In up to the present practice supported by previous regulations; these are two subsequent budget years. The government has the right to establish multiannual programs and determine the total amount of spending for their implementation. The legislator also pointed out that when establishing multiannual programs, the state should be guided by the implementation of its strategies, with particular emphasis on defence and security, although these areas should be treated as examples, as the actual scope of implemented multiannual programmes is much wider.

Table 1 illustrates the level of spending on multiannual programmes against the total state budget expenditure. It should be noted that in the analysed period the number of financed long-term programs ranges from 41 to 45 , and the total expenditure does not exceed 3\% of the state budget in any of the years. Among all programmes performed in the studied period, the largest spending was allocated to the National Roads Construction Programme for 2014-2023 (with a perspective to 2025). The expenditure on this programme amounted to as much as a half of the expenditure on all long-term programmes. 
TABLE 1

Expenditure for the performance of multiannual programmes 2014-2018

\begin{tabular}{|l|c|c|c|c|c|}
\hline \multicolumn{1}{|c|}{ Specification } & $\mathbf{2 0 1 4}$ & $\mathbf{2 0 1 5}$ & $\mathbf{2 0 1 6}$ & $\mathbf{2 0 1 7}$ & $\mathbf{2 0 1 8}$ \\
\hline $\begin{array}{l}\text { Budget Act } \\
\text { (in thousand PLN) }\end{array}$ & 9003665 & 11780713 & 13063896 & 16767892 & 16934248 \\
\hline $\begin{array}{l}\text { Plan after modifications } \\
\text { (in thousand PLN) }\end{array}$ & 9392982 & 10276092 & 7354119 & 14346334 & 9838382 \\
\hline $\begin{array}{l}\text { Performance } \\
\text { (in thousand PLN) }\end{array}$ & 8879664 & 9365872 & 6998457 & 10816242 & 9217161 \\
\hline $\begin{array}{l}\text { Share in state budget } \\
\text { expenditure }\end{array}$ & $2.84 \%$ & $2.82 \%$ & $1.90 \%$ & $2.88 \%$ & $2.36 \%$ \\
\hline $\begin{array}{l}\text { Number of imple- } \\
\text { mented programmes }\end{array}$ & 43 & 41 & 41 & 43 & 45 \\
\hline
\end{tabular}

Source: author's own elaboration according to: [Sprawozdanie..., 2014-2018].

In addition, attention should be paid to the fact that the performance of the plan of expenditures on multiannual programmes is lower than the total expenditures of the state budget, which may indicate an inappropriate way of calculating expenditures on specific programmes, especially from the point of view of their distribution in time over years of the implemented programmes. In the analysed period, it concerned, for example, such programs as the "Adam Mickiewicz University in Poznan 2004-2019", the "University of Warsaw 2016-2025", the "Construction of the Józef Piłsudski Museum complex in Sulejówek" and the "Construction of a waterway connecting the Vistula Lagoon with the Gulf of Gdansk". Among the reasons for the failure to execute the planned expenditure, there are, above all, prolonged public procurement procedures, preparatory works for the investment, delays in obtaining administrative decisions and postponements in execution works. This results in the extension of completion deadlines of the long-term programmes or the withdrawal from the execution of some of their tasks. The establishment of multiannual programmes should serve to increase the stability of financing those tasks of the state that transpire from the assumptions of the development policy. The analysis of the functioning of many of these programmes indicates, however, that the mere fact of establishing a multiannual programme is not a sufficient guarantee of the timely performance of tasks covered by such a programme. Furthermore, taking into account the small scale of funds allocated annually for their implementation (in relation to the total state budget expenditure), it can be concluded that they reflect the departure from the rule of budget annuality on a small scale. 


\section{Scale of non-expiring expenditures in the state budget and budgets of LGUs}

One of the manifestations of the deviation from respecting the rule of budget annuality is the possibility to defer the funds budgeted for a given year in the following financial year. Such appropriations shall be referred to as 'non-expiring funds'. These are expenses that were originally planned for a given financial year, but due to certain circumstances (e.g. delays in the implementation of investments caused by weather conditions or prolongation of tender procedures) it is necessary to implement them after the end of the financial year.

With regard to the state budget resources, by $15^{\text {th }}$ of December of the financial year, and by way of a regulation, the Council of Ministers may determine the list and a financial plan of non-expiring expenditures, after obtaining the opinion of the parliamentary committee responsible for the budget. The final deadline for the use of non-expiring funds is $31^{\text {st }}$ March of the following financial year (however, it is possible for the Council of Ministers to set a sooner deadline). If the non-expiring funds have not been utilised within the set deadline, they shall be transferred to the state budget revenue account within 21 days from the deadline for their use specified in the regulation. Expenses that have been increased in the course of budget performance by means of transfers made with the consent of the Minister of Finance and those related to the implementation of multiannual programs are excluded from the possibility of being qualified as non-expiring expenditures [Act, 2009, art. 181].

In the case of budgets of local government units, it is the body constituting local government units that may establish, by way of a resolution, the list of non-expiring expenses at the end of a financial year and set a deadline for the usage of each expense included in the list in the following financial year [Act, 2009, art. 263]. The legislator has limited the scope of expenses that may be considered as non-expiring, because the provision of Art. 263 par. 3 allows the list to include only unused amounts of expenses related to the performance of public procurement contracts, as well as contracts that are yet to be concluded, but as a result of a public procurement procedure that has already been completed a contractor has been effectively selected. The final deadline for expenses that do not expire at the end of a financial year is the $30^{\text {th }}$ of June of the following year.

Table 2 presents a summary of the planned and executed amounts of non-expiring expenditure for the period 2014-2018.

In none of the analysed years did the share of these expenses in the total state budget expenditure exceed 1\%. It should be noted that the increase in the amount of non-expiring expenditures during the analysed period is a result of the improved condition of the state budget, as much as the abandonment of the application of extending expenditures beyond the financial year in previous years was the result of budgetary difficulties. 
TABLE 2

Non-expiring expenditure in the State Budget in 2014-2018

\begin{tabular}{|l|c|c|c|c|c|}
\hline \multicolumn{1}{|c|}{ Specification } & $\mathbf{2 0 1 4}$ & $\mathbf{2 0 1 5}$ & $\mathbf{2 0 1 6}$ & $\mathbf{2 0 1 7}$ & $\mathbf{2 0 1 8}$ \\
\hline $\begin{array}{l}\text { Plan } \\
\text { (in thousand PLN) }\end{array}$ & - & - & 750333 & 1296622 & 5117403 \\
\hline $\begin{array}{l}\text { Performance } \\
\text { (in thousand PLN) }\end{array}$ & - & - & 708104 & 1011871 & 3794965 \\
\hline $\begin{array}{l}\text { Share in state budget } \\
\text { expenditure }\end{array}$ & - & - & $0.19 \%$ & $0.27 \%$ & $0.97 \%$ \\
\hline
\end{tabular}

Source: author's own elaboration according to: [Sprawozdanie..., 2014-2018].

A more flexible approach to spending the funds not used during the budget year in recent years is also evidenced by the fact that while the use of non-expiring expenditures in the implementation of the 2016 budget only related to 4 portions of the budget, in the 2017 budget it concerned 25, and in 2018 - 39 portions of the budget. At the same time, the increase in the possibility of using the funds over the period of the financial year resulted in a gradual decrease in the plans performance indicator for non-expiring funds from $94.3 \%$ in the case of funds that did not expire in 2016 down to $74.2 \%$ in the case of non-expiring funds of the 2018 budget. Although the deadline for using the non-expiring funds is $31^{\text {st }}$ March of the following financial year, the deadline for using the funds for financing the Local Government Roads Fund in the amount of PLN 1.1 billion that did not expire in 2018 was set at 31 $1^{\text {st }}$ December 2019, exceeding the provisions of the Public Finance Act. This was made possible by the consent to extend the spending of these funds by the Act of $6^{\text {th }}$ December 2018 amending the Act on Special Solutions Aimed at Implementation of the Budget Act for 2018, i.e., the so-called "budget circular act" and signalled a departure from the mode of establishing the list of non-expiring expenditures specified in the Public Finance Act. The presented data shows that the application of the mechanism of non-expiring measures is of an extraordinary nature and is rather a result of distortions in the process of spending budgetary funds rather than a form of pursuing an increase in the importance of long-term expenditures.

The share of non-expiring expenditures in the budgets of local government units is shown in table 3 .

As in the case of the state budget, similar importance is attached to non-expiring expenditures in the LGU budgets. Although in specific years, small differences in their share in expenditures of certain categories of local government units can be observed, it is only in the case of provinces that in 2014 their share exceeded 1\% of total expenditures. In the remaining years, their share was lower. It should be noted that among those expenditures, the majority are expenditures on property, which in particular years of the analysed period represented from $89 \%$ to almost $95 \%$ of the total non-expiring expenditures, which leads to a conclusion that also in the case of 
local government units the occurrence of non-expiring expenditures is a result of delays in the implementation of financial tasks from the budget of a given year.

TABLE 3

Non-expiring expenditures in the budgets of local government units in 2014-2018

\begin{tabular}{|l|c|c|c|c|c|}
\hline \multicolumn{1}{|c|}{ Specification } & $\mathbf{2 0 1 4}$ & $\mathbf{2 0 1 5}$ & $\mathbf{2 0 1 6}$ & $\mathbf{2 0 1 7}$ & $\mathbf{2 0 1 8}$ \\
\hline $\begin{array}{l}\text { Non-expiring } \\
\text { expenditure in total } \\
\text { (in thousand PLN) }\end{array}$ & 1271693 & 917814 & 1404678 & 2048867 & 1504394 \\
\hline $\begin{array}{l}\text { Share in LGU's } \\
\text { expenditure in total }\end{array}$ & $0.65 \%$ & $0.47 \%$ & $0.68 \%$ & $0.89 \%$ & $0.58 \%$ \\
\hline $\begin{array}{l}\text { Share in expenditure } \\
\text { of communes }\end{array}$ & $0.53 \%$ & $0.48 \%$ & $0.66 \%$ & $0.99 \%$ & $0.68 \%$ \\
\hline $\begin{array}{l}\text { Share in expenditure } \\
\text { of districts }\end{array}$ & $0.27 \%$ & $0.30 \%$ & $0.61 \%$ & $0.66 \%$ & $0.52 \%$ \\
\hline $\begin{array}{l}\text { Share in expenditure } \\
\text { of municipalities with } \\
\text { district status }\end{array}$ & $0.77 \%$ & $0.51 \%$ & $0.74 \%$ & $0.85 \%$ & $0.50 \%$ \\
\hline $\begin{array}{l}\text { Share in expenditure } \\
\text { of provinces }\end{array}$ & $1.20 \%$ & $0.48 \%$ & $0.63 \%$ & $0.75 \%$ & $0.38 \%$ \\
\hline
\end{tabular}

Source: author's own elaboration according to: [Informacja..., 2014-2018].

\section{Expenditure for undertakings in budgets of local government units}

A key element of multiannual financial forecasts (WPF) for the following years, from the point of view of their impact on the LGU budgets, is the list of undertakings understood as multiannual programmes, projects or tasks, including those related to: programmes financed with the participation of funds from the European Union budget and other non-refundable foreign funds, and public-private partnership agreements. Each undertaking included in the WPF is described by specifying the amount of commitments to be made and the amount of payments for expenditure in each year of the commitment implementation. In this way, it is possible to make commitments in a given financial year resulting in the expenditure from the budgets of the following years. This means that determining the expenditure for multiannual undertakings is a guarantee that they will be incurred in subsequent years. Therefore, it can be concluded that the WPF not only forecasts the financial situation of LGUs in the following years, but also determines the amounts to be allocated to the projects to be included in the budgets of future years. The list of undertakings is therefore a projection of current budget decisions whose financial consequences may be observed in the future, both from the point of view of generating expenses and from the point of view of the necessity to finance them. 
Table 4 shows the share of expenditures on undertakings in total expenditures of local government units during the years 2014-2019.

TABLE 4

Share of expenditures on undertakings of LGUs in total in the years 2014-2019

\begin{tabular}{|l|c|c|c|c|c|c|}
\hline \multicolumn{1}{|c|}{ Specification } & $\mathbf{2 0 1 4}$ & $\mathbf{2 0 1 5}$ & $\mathbf{2 0 1 6}$ & $\mathbf{2 0 1 7}$ & $\mathbf{2 0 1 8}$ & $\mathbf{2 0 1 9 *}$ \\
\hline In total, including: & $14.08 \%$ & $11.74 \%$ & $8.29 \%$ & $10.18 \%$ & $13.94 \%$ & $23.53 \%$ \\
\hline Provinces & $25.57 \%$ & $27.24 \%$ & $18.89 \%$ & $17.05 \%$ & $23.91 \%$ & $52.54 \%$ \\
\hline Districts & $7.65 \%$ & $6.34 \%$ & $4.57 \%$ & $7.73 \%$ & $11.40 \%$ & $15.23 \%$ \\
\hline $\begin{array}{l}\text { Municipalities with district } \\
\text { status }\end{array}$ & $18.41 \%$ & $13.87 \%$ & $11.57 \%$ & $12.65 \%$ & $15.41 \%$ & $30.25 \%$ \\
\hline Communes & $9.86 \%$ & $8.37 \%$ & $5.41 \%$ & $8.13 \%$ & $12.21 \%$ & $16.25 \%$ \\
\hline
\end{tabular}

*data for 2019 according to the WPFs submitted to the Ministry of Finance as of 5.11.2019.

Source: author's own elaboration according to: [Sprawozdania budżetowe, 2014-2019].

It should be noted that the implementation of undertakings by local government units burdens their budgets much more than the implementation of multiannual programs in the state budget. Any increase in the significance of undertakings in the implementation of LGU budgets in the analysed period is hardly noticeable. It should be emphasised that in each category of LGUs, the expenditure on property predominates among all expenditures on undertakings. What is important, among all LGUs, provinces by far enjoy the largest share of expenditures on undertakings in the total budget expenditure. This leads to a conclusion that budgets of provinces are to the greatest extent determined by expenditures of a long-term nature. This is primarily determined by the fact that in the budgets of provinces, the expenditure on property represents the highest share, which results from the specific character of tasks carried out on the provincial level (significant share of expenses on transport, communications and health care).

Particular importance of property expenditures in extending the planning and execution horizon of LGU budgets beyond the financial year is confirmed by the data contained in table 5 .

According to the analysed data, in the case of all local government units about a half of the expenses on property is related to continuation of investment projects commenced in previous years. However, the share of continued investment expenditures in property expenditures for all categories of territorial self-government units significantly decreased in 2016. It was then that a significant decrease in the share of property expenses in LGU budgets was noted, caused by the completion of tasks financed from the EU financial perspective for the years 2007-2013, with a delay in the use of funds from the financial perspective for the years 2014-2020. In the following years, the implementation of investment tasks accelerated again in LGU budgets, which resulted in an increased share of expenses of a long-term nature. 
TABLE 5

Share of LGU expenditure for continued investment projects in property expenditure in total

\begin{tabular}{|l|c|c|c|c|c|c|}
\hline Specification & $\mathbf{2 0 1 4}$ & $\mathbf{2 0 1 5}$ & $\mathbf{2 0 1 6}$ & $\mathbf{2 0 1 7}$ & $\mathbf{2 0 1 8}$ & $\mathbf{2 0 1 9 *}$ \\
\hline $\begin{array}{l}\text { In total, } \\
\text { including: }\end{array}$ & $45.78 \%$ & $42.33 \%$ & $31.63 \%$ & $40.49 \%$ & $51.55 \%$ & $70.67 \%$ \\
\hline Provinces & $36.77 \%$ & $40.07 \%$ & $19.73 \%$ & $29.13 \%$ & $31.94 \%$ & $78.91 \%$ \\
\hline Districts & $33.91 \%$ & $34.78 \%$ & $23.42 \%$ & $32.18 \%$ & $41.70 \%$ & $53.98 \%$ \\
\hline $\begin{array}{l}\text { Municipalities with } \\
\text { district status }\end{array}$ & $55.14 \%$ & $44.02 \%$ & $37.35 \%$ & $46.89 \%$ & $64.79 \%$ & $83.99 \%$ \\
\hline Communes & $44.21 \%$ & $43.81 \%$ & $32.99 \%$ & $41.50 \%$ & $50.83 \%$ & $62.81 \%$ \\
\hline
\end{tabular}

* data for 2019 according to the WPFs submitted to the Ministry of Finance as of 5.11.2019. Source: author's own elaboration according to: [Sprawozdania budżetowe, 2014-2019].

Among the solutions presented in the article it transpires that the expenses for undertakings, especially those related to the implementation of investment projects, to the greatest extent determine the extension of the time range of their implementation beyond the budget year. The remaining solutions, such as the non-expiring expenditures and multiannual programmes in the state budget, do not show a significant influence on the shape of future budgets.

\section{Conclusions}

The comparisons presented indicate a relatively insignificant role of budget expenditure extending beyond the financial year, which is the evidence of the strong standing of the budget annuality principle in Poland. Although for more than 10 years there have been solutions in place in the Polish public finance system to support the extension of the medium-term budget planning horizon, such as the Multiannual Financial Plan (WPFP) of the state and the multiannual financial forecast (WPF) of local government units, their impact on the shape of the annually adopted budgets of the state and local government units is limited. Other solutions allowing greater flexibility for budget expenditures, such as multiannual programs and non-expiring measures, also play a minor role in the implementation of expenditures. The role of expenditures extending beyond the financial year is not only not significant, and furthermore, it is difficult to notice any increasing tendency in their importance during the period under review. The only solution, whose application translates into a more significant departure from the rule of a budget annuality, are undertakings specified in the multiannual financial forecasts of local government units.

The findings presented provide a strong justification for the need to strengthen multiannual budget planning solutions and to link them more closely to the annually adopted budgets, especially with regard to the state budget. 


\section{References}

Act, 2009, Ustawa z 27 sierpnia 2009 r o finansach publicznych, t.j. Dz.U. 2019 poz. 869 z późn. zm.

Dylewski M., 2016, Problemy wykorzystania WPF w zarzqdzaniu finansami jednostki samorzqdu terytorialnego, „Studia Ekonomiczne. Zeszyty Naukowe Uniwersytetu Ekonomicznego w Katowicach”, nr 273, s. 49-61.

Dyrektywa Rady 2011/85/UE ₹ dnia 8 listopada 2011 r. w sprawie wymogów dla ram budżetowych państw członkowskich, 2011, Dziennik Urzędowy L306, z dn. 23.11.2011.

EU IFIs, 2018, Medium-Term Budgetary Frameworks. A contribution to definitions and identification of good practices, Network of EU Independent Fiscal Institutions, https://www.euifis.eu/images/MTBF_PAPER.pdf [date of entry: 04.09.2020].

Filipiak B.Z., 2016, Instrumenty $i$ narzedzia zarzqdzania długiem - ocena spójności z. wieloletnia prognoza finansowa, „Finanse Komunalne”, nr 11, s. 29-40.

Franek S., 2013, Wieloletnie planowanie budżetowe w podsektorze rzqdowym, Difin, Warszawa.

Gajl N., 1986, Finanse i prawo finansowe, WN PWN, Warszawa.

Informacja o wykonaniu budżetów jednostek samorzqdu terytorialnego, Ministerstwo Finansów, Warszawa, 2014-2018, https://www.gov.pl/web/finanse/sprawozdaniabudzetowe [date of entry: 04.09.2020].

Jędrzejczyk M., 2020, Wieloletnia prognoza finansowa w jednostkach samorzqdu terytorialnego, Towarzystwo Naukowe KUL, Lublin.

Owsiak S., 2017, Finanse publiczne. Wspótczesne ujęie, WN PWN, Warszawa.

Postuła M., 2017, Planowanie wieloletnie - fak.ty i mity, „Finanse Komunalne”, nr 10, s. $50-68$.

Roczność i wieloletniosś w finansach publicznych, 2014, Ruśkowski E. (red.), Lex, Warszawa.

Ruśkowski E., 2015, Wydatki sztywne budżetu państwa, „Zeszyty Prawnicze BAS”, nr 4(48), s. 9-21.

Salachna J.M., 2015, Dlaczego należy poprawic mechanizmy wieloletniej prognozy finansowej?, „Finanse Komunalne”, nr 1-2, s. 61-67.

Salachna J.M., 2016, C:y prawna regulacja w zakeresie wieloletniej prognozy finansowej ma sens?, „Finanse Komunalne”, nr 11, s. 5-12.

Sprawozdanie z. wykonania ustawy budżetowej, Ministerstwo Finansów, Warszawa, 20142018, https://www.gov.pl/web/finanse/sprawozdania-roczne [date of entry: 04.09.2020].

Sprawozdania budżetowe, Ministerstwo Finansów, Warszawa, 2014-2019, https:/ /www. gov.pl/web/finanse/sprawozdania-budzetowe [date of entry: 04.09.2020].

Sherwood M., 2015, Medium-term budgetary frameworks in the EU Member States, Discussion Paper 021, European Commission.

Uryszek T., 2018, Wieloletnia prognoza finansowa a zrównoważenie finansów sektora samorzadowego. Przyklad najwieksaych miast w Polsce, „Ekonomiczne Problemy Usług”, nr 129, s. 269-278, DOI: 10.18276/epu.2018.129-22.

Wildavsky A., 1986, Budgeting: A Comparative Theory of Budgetary Processes, Transaction Books, New Brunswick.

Założenia reformy systemu budżetowego, 2016, Ministerstwo Finansów, Warszawa. 